\title{
Controversies Regarding Use of Myeloid Growth Factors in Leukemia
}

\author{
Jacqueline N. Poston, MD, ${ }^{\mathrm{a}, \mathrm{b}, \mathrm{c}}$ and Pamela S. Becker, MD, PhD $\mathrm{Ph}^{\mathrm{b}, \mathrm{d}}$
}

\begin{abstract}
This review focuses on the data supporting the use of myeloid growth factors (MGFs) in patients being treated for acute myeloid leukemia, acute lymphoblastic leukemia, chronic myeloid leukemia, and hairy cell leukemia, for which neutropenia is a common complication of treatment. However, due to the lack of randomized trial data or conflicting results of clinical studies, comprehensive guidelines have been difficult to formulate. Moreover, to date, these diagnoses have not been addressed in the NCCN Clinical Practice Guidelines in Oncology (NCCN Guidelines) for MGFs. However, in most cases, the general principles have been included in the applicable NCCN Guidelines for each individual cancer site.
\end{abstract}

\section{Acute Myeloid Leukemia}

The 2 key goals of myeloid growth factor (MGF) use in the management of acute myeloid leukemia (AML) have been (1) a theoretical benefit for "priming" to improve efficacy of chemotherapy, and (2) reduction of neutropenia duration with the potential to reduce days of hospitalization and incidence of life-threatening infections. MGFs have been shown to drive growth of AML blasts ${ }^{1-4}$ and initiate cell cycle progression. ${ }^{5} \mathrm{~A}$ slight increase in cells entering S-phase was observed in patients who received granulocyte-macrophage colonystimulating factor (GM-CSF) between days 4 and 8 of induction chemotherapy compared with a decline in cells in S-phase for those receiving placebo. ${ }^{5}$ Enhancing entry into S-phase theoretically promotes an increased response to S-phase-specific drugs, such as cytarabine (ara-C), which is the cornerstone of treatment for AML. Ara-C is metabolized intracellularly by deoxycytidine kinase to the active metabolite, cytosine arabinoside tri-

From the aDivision of Medical Oncology, University of Washington; ${ }^{\mathrm{b} C l i n i c a l}$ Research Division, Fred Hutchinson Cancer Research Center; 'Seattle Cancer Care Alliance; and Division of Hematology, University of Washington, Seattle, Washington.

Submitted August 7, 2017; accepted for publication September 29, 2017.

The authors have disclosed that they have no financial interests, arrangements, affiliations, or commercial interests with the manufacturers of any products discussed in this article or their competitors. Dr. Poston phosphate (ie, ara-cytidine-5'-triphosphate [ara-CTP]), which competes with deoxycytidine triphosphate for incorporation into DNA, and leads to chain termination and block of DNA synthesis. Increases in intracellular ara-CTP levels are seen with MGFs, as well as increased rates of ara-CTP incorporation into DNA. ${ }^{6-8}$

Attempts were made to directly determine whether there was an increase in S-phase for patients receiving clinical growth factor on study and to determine whether there was a correlation with response. Additionally, more recent preclinical studies highlight various potential applications of growth factor strategies in the treatment of leukemia. For example, Padron et al $^{9}$ identified a hypersensitivity to GM-CSF in patients with chronic myelomonocytic leukemia, with signal transduction through the STAT-5 pathway. They suggest that a combination of growth factor plus JAK2 inhibitor may have clinical utility.

receives support from an institutional training grant from the National Heart, Lung, and Blood Institute (T32 HL007093). Dr. Becker has disclosed that she has received support from the NCI of the NIH (P01CA077852). The content is solely the responsibility of the authors, and does not necessarily represent the official views of the NIH.

Correspondence: Pamela S. Becker, MD, PhD, Institute for Stem Cell and Regenerative Medicine, 850 Republican Street N415, University of Washingon Campus Box 358056, Seattle, WA 98109.

E-mail: pbecker@seattlecca.org 
Another potential rationale for priming with growth factors is that they may mobilize cells out of the protected marrow microenvironment, rendering them more susceptible to chemotherapy. One preclinical study found that granulocyte colonystimulating factor (G-CSF) reduced the viability of AML cells in vitro when cocultured with HS-5 stroma cells, and that reduced clonogenic capacity after G-CSF treatment correlated with patients who achieved remission compared with those who were refractory. ${ }^{10}$ In another study, a preclinical model of the marrow niche constructed of osteoblast and stroma coated 3-dimensional (3D) scaffold demonstrated that "mobilization" of a leukemia cell line with the CXCR4 inhibitor plerixafor and G-CSF led to enhanced ara-C-induced cytotoxicity. ${ }^{11}$

G-CSF has an FDA-approved indication "for reducing the time to neutrophil recovery and the duration of fever, following induction or consolidation chemotherapy treatment of patients with AML."12 The listed side effects, with at least $2 \%$ difference in incidence, compared with placebo include epistaxis, back pain, pain in extremity, erythema, maculopapular rash, diarrhea, constipation, and transfusion reaction. Although the biosimilar filgrastim-sndz shares all indications granted to filgrastim, pegfilgrastim and tbo-filgrastim do not have an indication in AML. However, one trial that randomized patients to pegfilgrastim or filgrastim showed the drugs to be equivalent in terms of days to neutrophil count recovery after induction or consolidation and in terms of adverse events. ${ }^{13}$ GM-CSF also has an FDA-approved indication "for use following induction chemotherapy in older adult patients with acute myelogenous leukemia to shorten time to neutrophil recovery and to reduce the incidence of severe and life-threatening infections and infections resulting in death," and is applicable to patients aged $\geq 55$ years. ${ }^{14}$

One of the initial concerns regarding the use of MGFs in AML was the potential for driving proliferation of the blasts in patients undergoing treatment. For this reason, several of the clinical trials did not permit patients with high circulating blast counts to enroll. Although there are individual case reports of life-threatening increases in blast count with MGF administration, such as in a patient treated with pegfilgrastim ${ }^{15}$ in whom the blast count increased to $283 \times 10^{9} / \mathrm{L}$, in general, clinical trials with long-term follow-up that combined growth factor and chemo- therapy have not shown an increase in mortality or relapse rate (RR) with use of MGFs. ${ }^{16}$ To summarize, MGFs may be safely used in patients with AML, but the question remains whether they are beneficial.

One of the largest trials designed to address the impact of priming randomized 917 patients with AML to receive G-CSF versus no G-CSF during induction chemotherapy. ${ }^{17} \mathrm{~A}$ benefit in overall survival (OS; $P=.003)$ and event-free survival (EFS; $P=.01$ ) was only seen in patients who received $G$ CSF with a dose escalation of ara-C, suggesting that priming with G-CSF is particularly effective with higher doses of ara-C. A multicenter randomized controlled trial of 640 patients with newly diagnosed AML undergoing induction with G-CSF versus placebo showed a similar response rate after induction in both groups; however, the G-CSF group showed a reduced probability of relapse (RR, 0.77; 95\% CI, 0.61-0.99; P=.04). ${ }^{18}$ Within the group of patients who achieved a complete response after induction, those who received G-CSF had improved disease-free survival (DFS; 4-year DFS , $42 \%$ vs 33\%; $P=.02$ ). Notably, patients with an unfavorable prognosis did not receive a benefit from the use of G-CSF in the subgroup analysis.

Table 1 lists the details of a number of randomized trials that used G-CSF or GM-CSF in combination with chemotherapy for AML. ${ }^{19-31}$ Individual trials have shown a reduction in the duration of neutropenia for trials that continued growth factor treatment until neutrophil recovery, without any adverse effects on remission rate, EFS, or OS.

G-CSF has also been used to manage neutropenia and infectious complications in AML. The most extensive data analysis regarding the use of G-CSF is a Cochrane meta-analysis of 19 randomized controlled trials. ${ }^{32}$ This showed no benefit with the use of G-CSF, including no difference in mortality, OS, remission, DFS, and incidence of bacteremia and invasive fungal infections. Furthermore, there was a marginal increase in adverse events with growth factors, leading to discontinuation of CSFs, compared with the control arm (RR, 1.33; 95\% CI, 1.00-1.56).

One pediatric trial that assigned 258 patients with AML to induction therapy without G-CSF and then 254 patients to therapy with G-CSF ${ }^{33}$ reported earlier time to neutrophil recovery and shorter hospitalization without a difference in severe adverse events, remission rate, EFS, or OS. Another pedi- 


\section{Table 1. Randomized Trials of Myeloid Growth Factors in Acute Myeloid Leukemia}

\begin{tabular}{|c|c|c|c|c|c|c|c|c|c|}
\hline Study & $\begin{array}{l}\text { Treatment } \\
\text { Phase }\end{array}$ & $\begin{array}{l}\text { Age } \\
\text { Range, y }\end{array}$ & GF Type & GF Dose & $\begin{array}{l}\text { CR With vs } \\
\text { Without GF }\end{array}$ & $\begin{array}{l}\text { DFS (or RFS or } \\
\text { EFS) With vs } \\
\text { Without GF }\end{array}$ & $\begin{array}{l}\text { OS With vs } \\
\text { Without GF }\end{array}$ & Days of Fever & $\begin{array}{l}\text { Days to ANC } \\
\text { Recovery } \\
\left(0.5 \times 10^{9} / \mathrm{L}\right) \text { With } \\
\text { vs Without GF }\end{array}$ \\
\hline $\begin{array}{l}\text { Ohno et al, }{ }^{19} \\
1994\end{array}$ & Induction & $16-66$ & G-CSF & $\begin{array}{l}200 \mathrm{mcg} / \mathrm{m}^{2} \\
2 \text { days } \\
\text { pretreatment } \\
\text { to d35 }\end{array}$ & $\begin{array}{l}50 \% \text { vs } 37 \% \\
(P=.3)\end{array}$ & $P=.54$ & ND & 11.3 vs 9.6 & 24 vs 29 \\
\hline $\begin{array}{l}\text { Rowe et al, }{ }^{20} \\
1995\end{array}$ & Induction & $55-70$ & GM-CSF & $\begin{array}{l}\text { d11 until } \\
\text { recovery if } \\
\text { d10 marrow } \\
\text { is without } \\
\text { leukemia }\end{array}$ & $\begin{array}{l}60 \% \text { vs } 44 \% \\
(P=.08)\end{array}$ & $\begin{array}{l}\text { Median DFS: } \\
8.5 \text { vs } 9.6 \mathrm{mo} \\
(P=.95)\end{array}$ & $\begin{array}{l}\text { Median OS: } 10.6 \\
\text { vs } 4.8(P=.048)\end{array}$ & ND & $\begin{array}{l}13 \text { vs } 17 \\
(P=.001)\end{array}$ \\
\hline $\begin{array}{l}\text { Zittoun et } \\
\text { al, }^{21} 1996\end{array}$ & Induction & $17-59$ & GM-CSF & $\begin{array}{l}5 \mathrm{mcg} / \mathrm{kg} / \mathrm{d} \\
\mathrm{d} 0-7 \text { or d8-28 } \\
\text { or d0-28 }\end{array}$ & $\begin{array}{l}72 \% \text { d0-7, } \\
48 \% \text { d } 8-28,46 \% \\
\text { d0-28 vs } 77 \% \\
\text { ( } P=.008 \text { with vs } \\
\text { without GF) }\end{array}$ & $\begin{array}{l}P=.02 \text { for } \mathrm{d} 8-28 \\
\text { group vs not; } \\
P=.16 \text { for } \mathrm{GF} \\
\text { d0-7 group } \\
\text { vs not }\end{array}$ & ND & $\begin{array}{l}7,7,10.5 \text { vs } 5.5 \\
\text { (same } 4 \text { groups } \\
\text { as for } C R \text { ) }\end{array}$ & $\begin{array}{l}22.2,22.0,19.5 \\
\text { vs } 24.5 \text { (same } \\
4 \text { groups as } \\
\text { for CR) }\end{array}$ \\
\hline $\begin{array}{l}\text { Löwenberg } \\
\text { et } \mathrm{al}^{22} 1997\end{array}$ & Induction & $\geq 61$ & GM-CSF & $\begin{array}{l}5 \mathrm{mcg} / \mathrm{kg} / \mathrm{d} \text {, } \\
\mathrm{d} 0-28\end{array}$ & $\begin{array}{l}56 \% \text { vs } 55 \% \\
(P=.98)\end{array}$ & $\begin{array}{l}\text { 2-y: } 14 \% \text { vs } 19 \% \\
(P=.69)\end{array}$ & $\begin{array}{l}2 \text {-y } 22 \% \text { both } \\
\text { groups } \\
(P=.55)\end{array}$ & 10 vs $6(P<.001)$ & $\begin{array}{l}23 \text { vs } 25 \\
(P=.0002)\end{array}$ \\
\hline $\begin{array}{l}\text { Witz et al, }{ }^{23} \\
1998\end{array}$ & Induction & $55-75$ & GM-CSF & $\begin{array}{l}5 \mathrm{mcg} / \mathrm{kg} / \mathrm{d} \text {, } \\
\mathrm{d} 1-28\end{array}$ & $\begin{array}{l}63 \% \text { vs } 60.5 \% \\
(P=.79)\end{array}$ & $\begin{array}{l}2-y: 48 \% \text { vs } 21 \% \\
(P=.003)\end{array}$ & $\begin{array}{l}\text { Longer OS with } \\
\text { GF: } 39 \% \text { vs } 27 \% \\
(P=.082)\end{array}$ & 8 vs $10(P=.5)$ & $\begin{array}{l}24 \text { vs } 29 \\
(P=.0001)\end{array}$ \\
\hline $\begin{array}{l}\text { Godwin et } \\
\text { al, }^{24} 1998\end{array}$ & Induction & $56-88$ & G-CSF & $\begin{array}{l}400 \mathrm{mcg} / \mathrm{m}^{2} / \mathrm{d} \\
\text { d11-recovery }\end{array}$ & $\begin{array}{l}41 \% \text { vs } 50 \% \\
(P=.89)\end{array}$ & $\begin{array}{l}\text { Median RFS: } \\
8 \text { vs } 9 \text { mo }\end{array}$ & $\begin{array}{l}6 \text { vs } 9 \text { mo } \\
(P=.71)\end{array}$ & 8 vs $10(P=.091)$ & $\begin{array}{l}\text { Median: } \\
24 \text { vs } 27 \\
(P=.014)\end{array}$ \\
\hline $\begin{array}{l}\text { Thomas et } \\
\text { al, }^{5} 1999\end{array}$ & Salvage & $16-65$ & GM-CSF & $\begin{array}{l}5 \mathrm{mcg} / \mathrm{kg} / \mathrm{d} \\
\mathrm{d} 4-8\end{array}$ & $65 \%$ vs $59 \%$ & $\begin{array}{l}\text { Median DFS: } \\
251 \text { vs } 240 \text { d }\end{array}$ & $\begin{array}{l}\text { Median OS: } 303 \\
\text { vs } 254 \mathrm{~d}\end{array}$ & ND & 38 vs 37 \\
\hline $\begin{array}{l}\text { Estey et al, }{ }^{25} \\
1999\end{array}$ & Induction & $\geq 71$ & G-CSF & $\begin{array}{l}200 \mathrm{mcg} / \mathrm{m}^{2} / \mathrm{d} \\
\text { d0 until } \\
\text { recovery }\end{array}$ & $\begin{array}{l}55 \% \mathrm{FAl}+\mathrm{G}-\mathrm{CSF} \\
\text { vs } 40 \% \mathrm{FAl} \\
(P=.087)\end{array}$ & $\begin{array}{l}\text { EFS: } P=.95 \\
\text { FAI+G-CSF vs FAI }\end{array}$ & ND & ND & ND \\
\hline $\begin{array}{l}\text { Harousseau } \\
\text { et } \mathrm{al}^{26} 2000\end{array}$ & Consolidation & $15-60$ & G-CSF & $\begin{array}{l}5 \mathrm{mcg} / \mathrm{kg} / \mathrm{d} \text { from } \\
\text { day after chemo } \\
\text { until recovery }\end{array}$ & ND & $\begin{array}{l}\text { 2-y DFS: } 47 \% \text { vs } \\
43 \%\end{array}$ & $\begin{array}{l}2-y \text { actuarial OS: } \\
64 \% \text { vs } 63 \%\end{array}$ & 5 vs $6(P=.35)$ & $\begin{array}{l}12 \text { vs } 19 \text { first } \\
\text { consolidation }\end{array}$ \\
\hline $\begin{array}{l}\text { Löwenberg } \\
\text { et } \mathrm{all}^{18} 2003\end{array}$ & Induction & $18-60$ & G-CSF & $\begin{array}{l}150 \mathrm{mcg} / \mathrm{m}^{2} / \mathrm{d} \\
\mathrm{d} 0-8 \text { first cycle, } \\
\text { d0-6 second } \\
\text { cycle }\end{array}$ & $\begin{array}{l}79 \% \text { vs } 83 \% \\
(P=.24)\end{array}$ & $\begin{array}{l}\text { 4-y EFS: } 33 \% \text { vs } \\
28 \%(P=.17) \\
\text { Standard-risk } \\
\text { subset: } 39 \% \\
\text { vs } 29 \% \\
(P=.01)\end{array}$ & $\begin{array}{l}\text { 4-y OS: } 40 \% \text { vs } \\
35 \%(P=.16) \\
\text { Standard-risk } \\
\text { subset: } \\
45 \% \text { vs } 35 \% \\
(P=.02)\end{array}$ & ND & $\begin{array}{l}\text { Cycle 1: } 30 \text { vs } 30 \\
\text { Cycle 2: } 26 \text { vs } 25\end{array}$ \\
\hline $\begin{array}{l}\text { Rowe et al, }{ }^{27} \\
2004\end{array}$ & Induction & $56-86$ & GM-CSF & $\begin{array}{l}250 \mathrm{mcg} / \mathrm{m}^{2} / \mathrm{d} \\
48 \text { hours } \\
\text { prechemo until } \\
\text { d10 marrow } \\
\text { negative then } \\
\text { both GF and } \\
\text { placebo group } \\
\text { received GF } \\
\text { until ANC } \\
\text { recovery }\end{array}$ & $\begin{array}{l}38 \% \text { vs } 40 \% \\
\text { with or with GF } \\
\text { priming }\end{array}$ & $\begin{array}{l}\text { Median DFS: } 6.9 \\
\text { vs } 5.1 \mathrm{mo} \\
(P=.73)\end{array}$ & $\begin{array}{l}\text { Median OS: } 5.3 \\
\text { vs } 8.5 \mathrm{mo} \\
(P=.11)\end{array}$ & ND & ND \\
\hline $\begin{array}{l}\text { Amadori et } \\
\text { al, }{ }^{28} 2005\end{array}$ & Induction & $61-80$ & G-CSF & $\begin{array}{l}150 \mathrm{mcg} / \mathrm{m}^{2} / \mathrm{d} \\
\mathrm{d} 1-7 \text { or } \mathrm{d} 1 \text { or } \\
\mathrm{d} 8 \text { until } \mathrm{ANC} \\
\text { recovery }\end{array}$ & $\begin{array}{l}58.3 \% \text { for GF } \\
\text { during chemo } \\
\text { vs } 48.6 \% \text { for no } \\
\text { GF or GF after } \\
\text { chemo }(P=.009)\end{array}$ & $\begin{array}{l}\text { 3-y DFS: } 14.5 \%- \\
18.6 \% \text { vs } 21.5 \%\end{array}$ & $\begin{array}{l}3-y \text { OS: } 7.6 \%- \\
18.3 \% \text { vs } 15.2 \%\end{array}$ & $\begin{array}{l}8 \text { for groups } \\
\text { with GF until } \\
\text { recovery vs } 8.8 \\
\text { for no GF } \\
\text { or just d1-7 }\end{array}$ & $\begin{array}{l}20 \text { for groups } \\
\text { with GF until } \\
\text { recovery vs } 25 \\
\text { for no GF or just } \\
\text { d1-7 }(P<.001)\end{array}$ \\
\hline $\begin{array}{l}\text { Heil et al, }{ }^{29} \\
1997\end{array}$ & Induction & $16-89$ & G-CSF & $\begin{array}{l}5 \mathrm{mcg} / \mathrm{kg} / \mathrm{d}, \mathrm{d} 6 \\
\text { until recovery }\end{array}$ & $\begin{array}{l}69 \% \text { vs } 68 \% \\
(P=.77)\end{array}$ & $\begin{array}{l}\text { Median DFS: } \\
0.86 \text { vs } 0.79 \text { y }\end{array}$ & $\begin{array}{l}\text { Median OS: } \\
1.04 \text { vs } 1.13 \text { y }\end{array}$ & 7 vs $8.5(P=.009)$ & $\begin{array}{l}\text { Median } 20 \text { vs } \\
25(P=.0001)\end{array}$ \\
\hline \multicolumn{10}{|l|}{$\begin{array}{l}\text { Heil et al, }{ }^{16} \\
2006\end{array}$} \\
\hline $\begin{array}{l}\text { Thomas et } \\
\mathrm{al}^{30} 2007\end{array}$ & Induction & $15-49$ & GM-CSF & $\begin{array}{l}5 \mathrm{mcg} / \mathrm{kg} / \mathrm{d} \\
\mathrm{d} 1-10\end{array}$ & $\begin{array}{l}88 \% \text { vs } 77 \% \\
(P<.04)\end{array}$ & $\begin{array}{l}3 \text {-y EFS: } 42 \% \text { vs } \\
34 \%(P=.06) \\
\text { Median EFS: } \\
22.5 \text { vs } 15.5 \text { mo }\end{array}$ & $\begin{array}{l}\text { 3-y OS: } 54 \% \text { vs } \\
46 \% \\
\text { Median OS: } 40.4 \\
\text { vs } 29 \text { mo }\end{array}$ & ND & 31 vs 31 \\
\hline $\begin{array}{l}\text { Pabst et al, }{ }^{17} \\
2012\end{array}$ & Induction & $17-60$ & G-CSF & $\begin{array}{l}5 \mathrm{mcg} / \mathrm{kg} / \mathrm{d} \\
\mathrm{d} 0-7\end{array}$ & $\begin{array}{l}81 \% \text { vs } 77 \% \\
(P=.11)\end{array}$ & $\begin{array}{l}\text { 5-y DFS: } 37 \% \text { vs } \\
31 \%(P=.29) \\
\text { Escalated-dose } \\
\text { cytarabine } \\
\text { subset: } 43 \% \text { vs } \\
28 \%(P=.012)\end{array}$ & $\begin{array}{l}5 \text {-y OS: } 43 \% \text { vs } \\
40 \%(P=.88) \\
\text { Escalated-dose } \\
\text { cytarabine } \\
\text { subset: } 50 \% \text { vs } \\
30 \%(P=.003)\end{array}$ & ND & $\begin{array}{l}\text { Cycle } 1: 29 \text { vs } 29 \\
\text { Cycle 2: } 31 \text { vs } 28 \\
(P=.007)\end{array}$ \\
\hline $\begin{array}{l}\text { Stone et } \mathrm{al}^{31} \\
1995\end{array}$ & Induction & $>60$ & GM-CSF & $\begin{array}{l}5 \mathrm{mcg} / \mathrm{kg} / \mathrm{d}, \mathrm{d} 8 \\
\text { until recovery }\end{array}$ & $\begin{array}{l}51 \% \text { vs } 54 \% \\
(P=.61)\end{array}$ & ND & 0.7 vs $0.9 \mathrm{y}$ & ND & 15 vs 17 \\
\hline
\end{tabular}

Abbreviations: ANC, absolute neutrophil count; chemo, chemotherapy; CR, complete response; d0, day before chemotherapy begins; DFS, disease-free survival; EFS, eventfree survival; FAl, fludarabine/cytarabine/idarubicin; G-CSF, granulocyte colony-stimulating factor; GF, growth factor; GM-CSF, granulocyte-macrophage colony-stimulating factor; ND, not determined; OS, overall survival; RFS, relapse-free survival.

a Order of comparison is GF vs placebo. 
atric trial showed a reduction in days of neutropenia (18.0 vs 23.0 days; $P=.02$ after AIE [cytarabine, idarubicin, etoposide] for newly diagnosed AML), but no impact on the incidence of grade 3 and 4 infections. ${ }^{34}$ One retrospective trial focusing on G-CSF dosing found that patients who received $<5 \mathrm{mcg} / \mathrm{kg}$ of G-CSF had a significantly increased risk of developing neutropenic fever compared with those who received G-CSF at $\geq 5 \mathrm{mcg} / \mathrm{kg}$ ( $87 \%$ for $<5 \mathrm{mcg} / \mathrm{kg}$; $68 \%$ for $5 \mathrm{mcg} / \mathrm{kg}$; and $54 \%$ for $>5 \mathrm{mcg} / \mathrm{kg}) .{ }^{35}$

Although G-CSF does not appear to change overall outcomes, individual trials have shown a reduction in the duration of neutropenia, hospitalization, and antibiotic use. ${ }^{26,36}$ In a retrospective study, there was benefit to preemptive initiation of G-CSF after chemotherapy but before development of fever, with a shorter duration $(P<.001)$ and trend toward reduced mortality $(P=.076) .{ }^{36}$ In older patients (age $>55$ years), G-CSF has been shown to reduce the number of days spent febrile (thus leading to less antibiotic use) even though there was no difference in the total documented infections or number of fatal infections with G-CSF versus placebo. ${ }^{24}$ Even if GCSF does not equate to a survival benefit, there may be cases in which the use of G-CSF still provides a benefit; it is difficult to extrapolate the data to each particular patient or underlying infection.

Perhaps with better modern supportive care, including more options for antifungal prophylaxis and treatment, simply reducing days of neutropenia does not improve survival. Has the meta-analysis ${ }^{32}$ that did not show improved survival in patients with AML who received growth factor affected recommendations in the guidelines for growth factor use? In the current NCCN Guidelines for AML, ${ }^{37}$ the supportive care section states that "Growth factors may be considered as a part of supportive care for postremission therapy" (AML-C; to view the most recent version of these guidelines, visit NCCN.org). Note that such use may confound interpretation of the bone marrow evaluation. Patients should be off GM-CSF or G-CSF for a minimum of 7 days before bone marrow collection to document remission. For supportive care of acute promyelocytic leukemia, the guidelines state that MGFs should not be used in induction (AML-C). They may be considered during consolidation in selected cases (eg, life-threatening infections, signs/symptoms of sepsis); however, there are no outcomes data regarding the prophylactic use of MGFs in consolidation. ${ }^{37}$ The guidelines also note that "some regimens such as FLAG incorporate GCSF into the regimen" (MS-53, available online at NCCN.org). G-CSF and its dosing are included in the description in the publications on the regimens that include it. They also stated that, "Growth factors are not routinely recommended in postremission therapy, except in life-threatening infections or when signs and symptoms of sepsis are present and the leukemia is believed to be in remission" (MS-53). ${ }^{37}$

An alternative to the use of growth factors in the setting of life-threatening infection would be to use granulocyte transfusions, but a recent randomized multicenter trial did not show superiority of this treatment. ${ }^{38}$ There has not been a randomized trial of growth factors versus no growth factors in patients with AML who are neutropenic after chemotherapy and have a life-threatening infection; growth factors are simply empirically used based on the finding derived from the randomized studies that they might hasten neutrophil recovery.

\section{Acute Lymphoblastic Leukemia}

The current NCCN Guidelines for Acute Lymphoblastic Leukemia (ALL) recommend that G-CSF be used "for myelosuppressive blocks of therapy or as directed by treatment protocol" (ALL-C; to view the most recent version of these guidelines, visit NCCN.org). ${ }^{39}$ The individual clinical trials of pediatric/young adult versus adult chemotherapy differed regarding the incorporation of G-CSF; for example, the CALGB 10403 regimen $^{40}$ discouraged the routine use of MGFs and permitted them only in lifethreatening occurrences such as pneumonia, sepsis syndrome, or fungal infection, whereas HyperCVAD included G-CSF prophylaxis. ${ }^{41}$ There are few trials evaluating G-CSF use in HyperCVAD, although one trial evaluated the timing of its use, showing that G-CSF initiation could be moved safely from day 5 to day 10 with no significant difference in infection rate. ${ }^{42}$

The largest study of G-CSF use in ALL treatment was a joint analysis of 5 randomized trials regarding its use during induction chemotherapy in adolescent and adult patients. ${ }^{43}$ In the multivariate analysis, prophylactic use of G-CSF was associated with a reduced risk of relapse (hazard ratio [HR], 0.64; 
$P=.007)$ and treatment failure (HR, 0.67; P=.02). There was an improved OS in the T-cell ALL subgroup at a median follow-up of 5 years $(51 \% \pm 8 \%$ vs $29 \% \pm 9 \% ; P=.01)$ and among patients aged 21 to 40 years $(44 \% \pm 6 \%$ vs $27 \% \pm 6 \% ; P=.03)$.

Other trials specifically testing the role of G-CSF and induction chemotherapy in ALL have shown a reduction in the duration of neutropenia. ${ }^{44-48}$ However, whether this results in a clinically meaningful reduction in the rate of infections is unclear, and another trial showed no benefit in DFS or OS. ${ }^{49}$ It is likely that outcomes with MGFs will vary depending on the depth and duration of neutropenia associated with the particular regimen, leading to the NCCN recommendation that use of MGFs be confined to regimens associated with more pronounced myelosuppression.

\section{Chronic Myeloid Leukemia}

Development of neutropenia during treatment for chronic myeloid leukemia (CML) with tyrosine kinase inhibitors (TKIs) or omacetaxine is not infrequent, although no randomized trials have explored this issue. Heim et $\mathrm{al}^{50}$ described the use of G-CSF given 3 times weekly in 6 patients with neutropenia on imatinib. Akard et $\mathrm{a}^{51}$ described frequent grade 3/4 myelosuppression for patients with CML on omacetaxine, and the need to use G-CSF in 25\% of patients with chronic-phase and $10 \%$ of patients with accelerated-phase disease. Studies initially focused on the use of growth factor to prevent neutropenia, and later to see if concurrent administration of TKI and growth factor could improve response. One study on the use of filgrastim in patients with CML on imatinib who developed grade $\geq 3$ neutropenia found that all patients had an improvement in absolute neutrophil count (ANC) - 64\% of them to $\mathrm{ANC}>2 \times 10^{9} / \mathrm{L}$ within 21 days-and that the total time spent off imatinib declined from $21 \%$ to $6 \%$ $(P=.0008)$, with the number of patients experiencing major cytogenetic responses increasing from 1 to 5 of 11 patients. ${ }^{52}$ The doses were $5 \mathrm{mcg} / \mathrm{kg}$ either daily or 1 to 3 times weekly, titrated to maintain ANC $>1 \times 10^{9} / \mathrm{L}$.

A second study examined the use of filgrastim in 130 patients treated with dasatinib. ${ }^{53}$ Grade $\geq 3$ neutropenia or thrombocytopenia occurred in $52 \%$ of patients; management included interruption of da- satinib in $37 \%$ and filgrastim administration in $14 \%$ at a dose of 300 or 480 mcg daily for 2 to 7 days per week, titrated to maintain $\mathrm{ANC}>1 \times 10^{9} / \mathrm{L}$. After initiation of filgrastim, 5 of 9 patients experienced an improved cytogenetic response.

The concept of finding a mechanism to eradicate leukemia stem cells led to the study of concomitant growth factor with TKI in an effort to sensitize the leukemia stem cells by inducing cell cycle. One randomized phase II trial compared continuous versus pulsed imatinib in patients with chronic-phase CML who had at least a complete cytogenetic response while on imatinib. ${ }^{54}$ Findings showed no difference in progression rates between the arms, and that the growth factor itself was not associated with a benefit in terms of reduction in BCR-ABL1 transcript levels. Moreover, a mathematical model predicted no therapeutic benefit of adding filgrastim to imatinib. ${ }^{55}$

The NCCN Guidelines for CML recommend that growth factors, in combination with imatinib, dasatinib, nilotinib, bosutinib, or ponatinib, can be used to manage neutropenia and thrombocytopenia (to view the most recent version of these guidelines, visit NCCN.org)..$^{56}$

\section{Hairy Cell Leukemia}

Recommendations vary regarding the role of G-CSF in hairy cell leukemia (HCL). In general, the recommendation is to consider MGFs on a case-by-case basis in patients with active infections. ${ }^{57,58}$ However, the rate of neutropenia is high, ranging from $30 \%$ to $50 \%,{ }^{59}$ which meets the threshold for recommended use of growth factors in the NCCN Guidelines for MGFs. These guidelines suggest the use of growth factors for regimens that are associated with a high risk of febrile neutropenia ( $>20 \%$ ) or an with intermediate risk $(10 \%-20 \%)$ in patients who have additional risk factors, such as age $>65$ years, hepatic or renal dysfunction, prior chemoradiotherapy, tumor involvement of the bone marrow, or recent surgery. ${ }^{60}$

A phase II trial compared the use of filgrastim prophylaxis with a cladribine-based regimen versus historical controls who did not receive G-CSF. ${ }^{61} \mathrm{~Pa}$ tients received filgrastim priming on days -3 through -1 , then continued it through chemotherapy and until the ANC was $>2 \times 10^{9} / \mathrm{L}$ for 2 consecutive days. A reduction in the duration of neutropenia was seen compared with historical controls (9 vs 22 days; 
Poston and Becker

$P<10^{-5}$ ), but no difference was seen in the rate of neutropenic fever, days with fever, or frequency of admissions for antibiotics. These findings support the consideration of MGFs on an individual basis rather than for routine prophylaxis.

\section{Conclusions}

One meta-analysis ${ }^{31}$ of 19 clinical trials of G-CSF in AML did not show any meaningful advantage favoring growth factor use. However, individual randomized large studies did find specific circumstances that led to an advantage with G-CSF use in patients with standard-risk $\mathrm{AML}^{18}$ or in those treated with a higher dose of ara-C. ${ }^{17}$ GM-CSF may also benefit selected patients with AML, but on a practical level, GM-CSF use has become infrequent. G-CSF may be helpful in ALL with selected regimens when there is appreciable risk of prolonged and profound neutropenia. G-CSF has permitted the continuation of treatment for patients with CML who sustain neutropenia with the use of TKIs or omacetaxine, and is recommended to be considered in individual cases of HCL with higher risk of developing neutropenia, such in patients aged $>65$ years. For these leukemias, guidelines for the use of MGFs are addressed in the individual disease-specific NCCN Guidelines rather than in the "Supportive Care" section of the NCCN Guidelines for MGF (to view the most recent version of all guidelines, visit NCCN.org).

\section{References}

1. Griffin JD, Young D, Herrmann F, et al. Effects of recombinant human GM-CSF on the proliferation of clonogenic cells in acute myeloblastic leukemia. Blood 1986;67:1448-1453.

2. Vellenga E, Young DC, Wagner K, et al. The effects of GM-CSF and G-CSF in promoting growth of clonogenic cells in acute myeloblastic leukemia. Blood 1987;69:1771-1776.

3. Miyauchi J, Kelleher CA, Yang Y, et al. The effects of three recombinant growth factors, IL-3, GM-CSF and G-CSF on the blast cells of acute myeloblastic leukemia maintained in short-term suspension culture. Blood 1987;70:657-663.

4. Motoji T, Takanashi M, Fuchinoue M, et al. Effect of recombinant GMCSF and recombinant G-CSF on colony formation of blast progenitors in acute myeloblastic leukemia. Exp Hematol 1989;17:56-60.

5. Thomas X, Fenaux P, Dombret H, et al. Granulocyte-macrophage colonystimulating factor (GM-CSF) to increase efficacy of intensive sequential chemotherapy with etoposide, mitoxantrone and cytarabine (EMA) in previously treated acute myeloid leukemia: a multicenter randomize placebo-controlled trial (EMA91 trial). Leukemia 1999;13:1214-1220.

6. Bhalla K, Birkhofer M, Arlin Z, et al. Effect of recombinant GM-CSF on the metabolism of cytosine arabinoside in normal and leukemic human bone marrow cells. Leukemia 1988;2:810-813.

7. Miyauchi J, Kelleher CA, Wang C, et al. Growth factors influence the sensitivity of leukemic stem cells to cytosine arabinoside in culture. Blood 1989;73:1272-1278.

8. Tanaka M. Recombinant GM-CSF modulates the metabolism of cytosine arabinoside in leukemic cells in bone marrow. Leuk Res 1993;17:585-592.

9. Padron E, Painter JS, Kunigal S, et al. GM-CSF-dependent pSTAT5 sensitivity is a feature with therapeutic potential in chronic myelomonocytic leukemia. Blood 2013;121:5068-5077.

10. Nomdedeu M, Lara-Castillo MC, Etxabe A, et al. Treatment with G-CSF reduces acute myeloid leukemia blast viability in the presence of bone marrow stroma. Cancer Cell Int 2015;15:122.

11. Shen ZH, Zeng DF, Kong PY, et al. AMD3100 and G-CSF disrupt the cross-talk between leukemia cells and the endosteal niche and enhance their sensitivity to chemotherapeutic drugs in biomimetic polystyrene scaffolds. Blood Cells Mol Dis 2016;59:16-24.

12. Amgen, Inc. Neupogen [filgrastim]. Available at: http://www.neupogenhcp. com/. Accessed October 26, 2017

13. Sierra J, Szer J, Kassis J, et al. A single dose of pegfilgrastim compared with daily filgrastim for supporting neutrophil recovery in patients treated for low-to-intermediate risk acute myeloid leukemia: results from a randomized, double-blind, phase 2 trial. BMC Cancer 2008;8:195.

14. LEUKINE [package insert]. Bridgewater, NJ: sanofi-aventis; 2013.

15. Duval C, Boucher S, Moulin JC, et al. Fatal stimulation of acute myeloid leukemia blasts by pegfilgrastim. Anticancer Res 2014;34:6747-6748.

16. Heil G, Hoelzer D, Sanz MA, et al. Long-term survival data from a phase 3 study of filgrastim as an adjunct to chemotherapy in adults with de novo acute myeloid leukemia. Leukemia 2006;20:404-409.

17. Pabst T, Vellenga E, van Putten W, et al. Favorable effect of priming with granulocyte colony-stimulating factor in remission induction of acute myeloid leukemia restricted to dose escalation of cytarabine. Blood 2012;119:5367-5373.

18. Löwenberg B, van Putten W, Theobald M, et al. Effect of priming with granulocyte colony-stimulating factor on the outcome of chemotherapy for acute myeloid leukemia. N Engl J Med 2003;349:743-752.

19. Ohno R, Naoe T, Kanamaru A, et al. A double-blind controlled study of granulocyte colony-stimulating factor started two days before induction chemotherapy in refractory acute myeloid leukemia. Kohseisho Leukemia Study Group. Blood 1994;83:2086-2092.

20. Rowe JM, Andersen JW, Mazza JJ, et al. A randomized placebo-controlled phase III study of granulocyte-macrophage colony-stimulating factor in adult patients ( $>55$ to 70 years of age) with acute myelogenous leukemia: a study of the Eastern Cooperative Oncology Group (E1490). Blood 1995;86:457-462

21. Zittoun R, Suciu S, Mandelli F, et al. Granulocyte-macrophage colonystimulating factor associated with induction treatment of acute myelogenous leukemia: a randomized trial by the European Organization for Research and Treatment of Cancer Leukemia Cooperative Group. J Clin Oncol 1996;14:2150-2159.

22. Löwenberg B, Suciu S, Archimbaud E, et al. Use of recombinant GMCSF during and after remission induction chemotherapy in patients aged 61 years and older with acute myeloid leukemia: final report of AML 11, a phase III randomized study of the Leukemia Cooperative Group of European Organisation for the Research and Treatment of Cance and the Dutch Belgian Hemato-Oncology Cooperative Group. Blood 1997;90:2952-2961.

23. Witz F, Sadoun A, Perrin MC, et al. A placebo-controlled study of recombinant human granulocyte-macrophage colony-stimulating factor administered during and after induction treatment for de novo acute myelogenous leukemia in elderly patients. Groupe Ouest Est Leucémies Aiguës Myéloblastiques (GOELAM). Blood 1998;91:2722-2730.

24. Godwin JE, Kopecky KJ, Head DR, et al. A double-blind placebocontrolled trial of granulocyte colony-stimulating factor in elderly patients with previously untreated acute myeloid leukemia: a Southwest Oncology Group study (9031). Blood 1998;91:3607-3615.

25. Estey EH, Thrall PF, Pierce S, et al. Randomized phase II study of fludarabine + cytosine arabinoside + idarubicin \pm all-trans retinoic acid \pm granulocyte colony-stimulating factor in poor prognosis newly diagnosed acute myeloid leukemia and myelodysplastic syndrome. Blood 1999;93:2478-2484.

26. Harousseau JL, Witz B, Lioure B, et al. Granulocyte colony-stimulating factor after intensive consolidation chemotherapy in acute myeloid leukemia: results of a randomized trial of the Groupe Ouest-Est Leucémies Aigues Myeloblastiques. J Clin Oncol 2000;18:780-787. 
Myeloid Growth Factors in Leukemia

27. Rowe JM, Neuberg D, Friedenberg W, et al. A phase 3 study of three induction regimens and of priming with GM-CSF in older adults with acute myeloid leukemia: a trial by the Eastern Cooperative Oncology Group. Blood 2004;103:479-485.

28. Amadori S, Suciu S, Jehn U, et al. Use of glycosylated recombinant human G-CSF (lenograstim) during and/or after induction chemotherapy in patients 61 years of age and older with acute myeloid leukemia: final results of AML-13, a randomized phase-3 study. Blood 2005;106:27-34.

29. Heil G, Hoelzer D, Sanz MA, et al. A randomized, double-blind, placebocontrolled, phase III study of filgrastim in remission induction and consolidation therapy for adults with de novo acute myeloid leukemia. Blood 1997;90:4710-4718.

30. Thomas X, Raffoux E, Botton SD, et al. Effect of priming with granulocytemacrophage colony-stimulating factor in younger adults with newly diagnosed acute myeloid leukemia: a trial by the Acute Leukemia French Association (ALFA) Group. Leukemia 2007;21:453-461.

31. Stone RM, Berg DT, George SL, et al. Granulocyte-macrophage colonystimulating factor after initial chemotherapy for elderly patients with primary acute myelogenous leukemia. Cancer and Leukemia Group B. N Engl J Med 1995;332:1671-1677.

32. Gurion R, Belnik-Plitman Y, Gafter-Gvili A, et al. Colony-stimulating factors for prevention and treatment of infectious complications in patients with acute myelogenous leukemia. Cochrane Database Syst Rev 2012;6:CD008238.

33. Alonzo TA, Kobrinsky NL, Aledo A, et al. Impact of granulocyte colonystimulating factor use during induction for acute myelogenous leukemia in children: a report from the Children's Cancer Group. J Pediatr Hematol Oncol 2002;24:627-635.

34. Creutzig U, Zimmermann $M$, Lehrnbecher $T$, et al. Less toxicity by optimizing chemotherapy, but not by addition of granulocyte colonystimulating factor in children and adolescents with acute myeloid leukemia: results of AML-BFM 98. J Clin Oncol 2006;24:4499-4506.

35. Hockings JK, Owolabi DK, Broyles JE, Wheelis SC. Impact of recommended weight-based dosing of granulocyte-colony factors in acute leukemia and stem cell transplant patients. Support Care Cancer 2017;25:1853-1858.

36. Kang KW, Kim DS, Lee SR, et al. Effect of granulocyte colony-stimulating factor on outcomes in patients with non-M3 acute myelogenous leukemia treated with anthracycline-based induction $(7+3$ regimen) chemotherapies. Leuk Res 2017;57:1-8.

37. O'Donnell MR, Tallman MS, Abboud CN, et al. NCCN Clinical Practice Guidelines in Oncology: Acute Myeloid Leukemia. Version 3.2017. J Natl Compr Canc Netw 2017;15:926-957.

38. Price TH, Boeckh M, Harrison RW, et al. Efficacy of transfusion with granulocytes from G-CSF/dexamethasone-treated donors in neutropenic patients with infection. Blood 2015;126:2153-2161.

39. Brown PA, Advani A, Aoun P, et al. NCCN Clinical Practice Guidelines in Oncology: Acute Lymphoblastic Leukemia. Version 1.2017. Accessed July 3, 2017. To view the most recent version of these guidelines, visit NCCN.org.

40. Advani AS, Sanford B, Luger S, et al. Frontline-treatment of acute lymphoblastic leukemia (ALL) in older adolescents and young adults (AYA) using a pediatric regimen is feasible: toxicity results of the prospective US Intergroup trial C10403 (Alliance) [abstract]. Blood 2013;122:Abstract 3903.

41. Thomas DA, O'Brien S, Faderl S, et al. Chemoimmunotherapy with a modified hyper-CVAD and rituximab regimen improves outcome in de novo Philadelphia chromosome-negative precursor B-lineage acute lymphoblastic leukemia. J Clin Oncol 2010;28:3880-3889.

42. Weiser MA, O'Brien $S$, Thomas DA, et al. Comparison of two different schedules of granulocyte-colony-stimulating factor during treatment for acute lymphocytic leukemia with a hyper-CVAD (cyclophosphamide, doxorubicin, vincristine, and dexamethasone) regimen. Cancer 2002;94:285-291.

43. Giebel S, Thomas $X$, Hallbook $\mathrm{H}$, et al. The prophylactic use of granulocyte-colony stimulating factor during remission induction is associated with increased leukaemia-free survival of adults with acute lymphoblastic leukemia: a joint analysis of five randomised trials on behalf of the EWALL. Eur J Cancer 2012;48:360-367.

44. Ottmann OG, Hoelzer D, Gracien E, et al. Concomitant granulocyte colony-stimulating factor and induction chemoradiotherapy in adult acute lymphoblastic leukemia: a randomized phase III trial. Blood 1995;86:444450.

45. Welte K, Reiter A, Mempel K, et al. A randomized phase-III study of the efficacy of granulocyte colony-stimulating factor in children with high-risk acute lymphoblastic leukemia. Berlin-Frankfurt-Münster Study Group. Blood 1996;87:3143-3150.

46. Geissler K, Koller E, Hubmann E, et al. Granulocyte colonystimulating factor as an adjunct to induction chemotherapy for adult acute lymphoblastic leukemia-a randomized phase-III study. Blood 1997;90:590-596.

47. Larson RA, Dodge RK, Linker CA, et al. A randomized controlled trial of filgrastim during remission induction and consolidation chemotherapy for adults with acute lymphoblastic leukemia: CALGB study 9111. Blood 1998;92:1556-1564.

48. Ozkaynak MF, Krailo M, Chen Z, Feusner J. Randomized comparison of antibiotics with and without granulocyte colony-stimulating factor in children with chemotherapy-induced febrile neutropenia: a report from the Children's Oncology Group. Pediatr Blood Cancer 2005;45:274-280.

49. Heath JA, Steinherz PG, Altman A, et al. Human granulocyte colonystimulating factor in children with high-risk acute lymphoblastic leukemia: a Children's Cancer Group Study. J Clin Oncol 2003;21:1612-1617.

50. Heim D, Ebnöther M, Meyer-Monard S, et al. G-CSF for imatinib-induced neutropenia. Leukemia 2003;17:805-807.

51. Akard L, Kantarjian HM, Nicolini FE, et al. Incidence and management of myelosuppression in patients with chronic- and accelerated-phase chronic myeloid leukemia treated with omacetaxine mepesuccinate. Leuk Lymphoma 2016;57:654-665.

52. Quintas-Cardama, Kantarjian H, O'Brien S, et al. Granulocyte-colony stimulating factor (filgrastim) may overcome imatinib-induced neutropenia in patients with chronic-phase chronic myelogenous leukemia. Cancer 2004;100:2592-2597.

53. Quintas-Cardam A, De Souza Santos FP, Kantarjian H, et al. Dynamics and management of cytopenias associated with dasatinib therapy in patients with chronic myeloid leukemia in chronic phase after imatinib failure. Cancer 2009;115:3935-3943.

54. Gallipoli P, Stobo J, Heaney N, et al. Safety and efficacy of pulsed imatinib with or without G-CSF versus continuous imatinib in chronic phase chronic myeloid leukemia patients at 5 years follow-up. Br J Haematol 2013;163:674-676.

55. Foo J, Drummond MW, Clarkson B, et al. Eradication of chronic myeloid leukemia stem cells: a novel mathematical model predicts no therapeutic benefit of adding G-CSF to imatinib. PLoS Comput Biol 2009;5:e1000503.

56. Pallera A, Altman JK, Berman E, et al. NCCN Guidelines Insights: Chronic Myeloid Leukemia. Version 1.2017. J Natl Compr Canc Netw 2016;14:1505-1512.

57. Grever MR, Abdel-Wahab O, Andritsos LA, et al. Consensus guidelines for the diagnosis and management of patients with classic hairy cell leukemia. Blood 2017;129:553-560.

58. Cornet E, Delmer A, Feugier P, et al. Recommendations of the SFH (French Society of Haematology) for the diagnosis, treatment and followup of hairy cell leukemia. Ann Hematol 2014;93:1977-1983.

59. Thompson PA, Ravandi F. How I manage patients with hairy cell leukaemia. Br J Haematol 2017;177:543-556.

60. Crawford J, Becker PS, Armitage J, et al. NCCN Clinical Practice Guidelines in Oncology: Myeloid Growth Factors. Version 1.2017. Accessed July 3, 2017. To view the most recent version of these guidelines, visit NCCN.org.

61. Saven A, Burian C, Adusumalli J, Koziol JA. Filgrastim for cladribineinduced neutropenic fever in patients with hairy cell leukemia. Blood 1999;93:2471-2477. 